\title{
Urban green areas and real estate prices in Curitiba, Brazil
}

We attempted to identify to which extent the implicit ecosystem service values of urban green areas impact real estate values in the city of Curitiba, Brazil. The study is based on spatial econometrics techniques and hedonic price theory applied to 43 urban green areas, highlighting three units: the Airumã Private Natural Heritage Reserve, the Teresa Urban Ecological Station, and the President Getulio Vargas Refinery. Information was obtained on the structural characteristics of more than 5,300 apartments and houses. The results of exploratory spatial data analysis (ESDA) and estimates from hedonic regression model parameters show that the presence of urban green areas contribute to the final property prices. The effects of proximity to urban green areas on the price of urban residential property are not homogeneous and stationary throughout urban spaces and can generate distinct spatial clusters of real estate prices: high-high and low-low. The used methodology proved to be efficient to assess the value of urban green areas with regard to the use of information, processing, data analysis, and results generated. Furthermore, it measured the impact of these areas on property prices and provided easily interpretable data that can be relevant for payments for ecosystem services policies at the local level.

Keywords: Green infrastructure; Land use options; Spatial hedonic regression; Housing prices.

\section{Áreas verdes urbanas e preços de imóveis em Curitiba, Brasil}

O presente artigo tem como objetivos avaliar o impacto das áreas verdes urbanas nos preços de apartamentos e de casas no município de Curitiba, PR, e propor uma metodologia para valoração de serviços ecossistêmicos gerados por áreas verdes urbanas. O estudo teve por base técnicas de econometria espacial e a Teoria dos Preços Hedônicos, aplicadas em 43 áreas verdes urbanas, destacando-se três unidades: Reserva Particular do Patrimônio Natural Municipal Airumã; Estação Ecológica Teresa Urban; e, Refinaria Presidente Getúlio Vargas (Repar). Foram obtidas informações sobre as características estruturais de 2.832 apartamentos e de 2.500 casas. Apresentou-se resultados da Análise Exploratória de Dados Espaciais (AEDE) e as estimações de parâmetros dos modelos de regressão hedônicos (Teoria dos Preços Hedônicos). Os resultados revelaram que as áreas verdes urbanas contribuem para a formação do preço final do imóvel. Igualmente, deve-se considerar que os efeitos de áreas verdes urbanas públicas ou privadas sobre o preço de imóveis residenciais urbanos não são homogêneos e estacionários ao longo do espaço urbano, podendo gerar distintos clusters espaciais de preços de imóveis: alto-alto e baixo-baixo. A metodologia apresentada para avaliação da valoração das áreas verdes urbanas mostrou-se eficiente quanto ao uso das informações, processamento, análise de dados e resultados gerados. Ainda, mensurou o impacto dessas áreas nos preços dos imóveis e forneceu subsídios de fácil interpretação para remuneração de Pagamento por Serviços Ambientais (PSA).

Palavras-chave: Infraestrutura verde; Opções de Uso da Terra; Regressão Hedônica Espacial; Preços de Imóveis.

Topic: Ciências Florestais

Reviewed anonymously in the process of blind peer.
Received: 07/10/2020

Approved: 19/11/2020
Alessandro Panasolo (iD

Universidade Federal do Paraná, Brasil http://lattes.cnpq.br/7596800563730823 http://orcid.org/0000-0002-5557-0049 apanasolo@gmail.com

\section{Franklin Galvão (iD}

Universidade Federal do Paraná, Brasil http://lattes.cnpq.br/6639659544951286 http://orcid.org/0000-0002-1425-1607 fgalvao@ufpr.br

Hermes Yukio Higachi (iD)

Universidade Estadual de Ponta Grossa, Brasil http://lattes.cnpq.br/3097395499530969 http://orcid.org/0000-0002-6064-4532 hhigachi@uepg.br

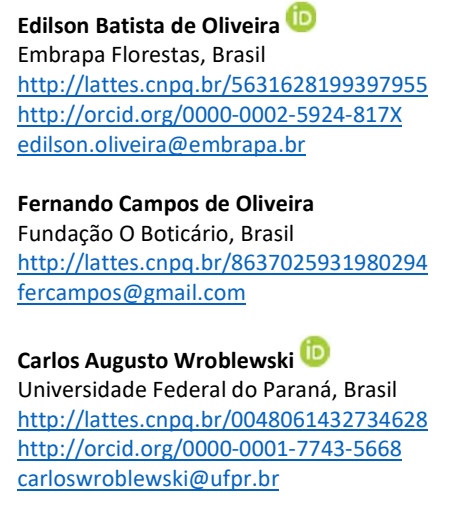

Tatiana Maria Cecy Gadda (D)

Universidade Tecnológica Federal do Paraná, Brasil http://lattes.cnpq.br/1544476939496232

http://orcid.org/0000-0002-7918-2104 tatianagadda@utfpr.edu.br

Camila Fossa Balbinot (iD

Instituto Romeu Felipe Bacelar, Brasil

http://orcid.org/0000-0002-9357-5473 camilabalbinot@gmail.com

\section{Referencing this:}

PANASOLO, A.; GALVÃO, F.; HIGACHI, H. Y.; OLIVEIRA, E. B.; OLIVEIRA, F. C.; WROBLEWSKI, C. A.; GADDA, T. M. C.; BALBINOT, C. F.. Urban green areas and real estate prices in Curitiba, Brazil. Revista Ibero Americana de Ciências Ambientais, v.11, n.6, p.86-102, 2020. DOI: http://doi.org/10.6008/CBPC2179-6858.2020.006.0008 


\section{INTRODUCTION}

Currently, more than $50 \%$ of the world's population lives in urban centers, and by the year 2050 , this number is projected to reach $66 \%$, which represents approximately 6 billion people, according to recent estimates (UN, 2014). The Economics of Ecosystems and Biodiversity (BRINK, 2011) recommends the Hedonic Price Method for case studies of valuation of urban ecosystem services.

To connect ecosystem services to monetary value, Bateman et al. (2010) indicate the hedonic analysis as the most relevant approach in the real estate market. This method is widely disseminated and used in economic theory, having several applications in the area of environmental economics, especially about air quality (BAJARI et al., 2012) and environmental liabilities (GAMPER-RABINDRAN et al., 2011). It is the best known and accepted method to assess the amenities of the urban forest (SANDER et al., 2010; ZYGMUNT et al., 2015), however, it is important to note that most of the previous hedonic studies on urban forest amenities were carried out in developed countries where data housing transactions are easy to access (MEl et al., 2018).

The valuation study of ecosystem services responsible for urban amenities, which represent a set of specific characteristics of a locality, with positive or negative contribution to the satisfaction of individuals (among them urban green areas) is important for understanding the impact of the urban environment on individuals. Partly because differences in income, education and pollution levels can lead to different preferences about such amenities. Thus, any change in the physical space of the cities may have consequences on the price of housing and the well-being of individuals (MEI et al., 2018).

The provision of multiple and often non-replaceable ecosystem services generated by these green areas makes these amenities fundamental in the urban economic context (HAURU et al., 2012). Families seek to locate themselves close to places with environmental, natural and historical benefits (VOTSIS, 2017). Therefore, the presence or absence of these urban ecosystem services is mainly involved in the well-being of people, so that the choices of individuals depend, in addition to the preference for a set of material goods, partly of non-material goods reflecting the quality of life of urban centers (VOTSIS, 2017).

In this paper, we applied the exploratory analysis of spatial data of apartments and house prices to estimate the impact of urban green areas, using spatial regression models, in order to answer three main questions: (i) "Is it possible to apply hedonic price theory and spatial econometric techniques to formulate a valuation methodology for ecosystem services generated by urban green areas in cities of developing countries?"; (ii) "Do urban green areas contribute to the formation of the final price of residences in Curitiba?"; and, (iii) "Considering the socioeconomic heterogeneity of the cities, should public policies, such as payment for environmental services (PES), be deployed in a sectored way?

\section{MATERIALS AND METHODS}

\section{Study area}

The study area was the city of Curitiba, capital of the State of Paraná, located in southern Brazil between $25^{\circ} 20^{\prime}$ and $25^{\circ} 38^{\prime} \mathrm{S}$ latitude and $49^{\circ} 11^{\prime}$ and $40^{\circ} 23^{\prime} \mathrm{W}$ longitude, with an area of $432,17 \mathrm{~km}^{2}$ and 
average altitude of 934 meters above sea level (m a.s.l.), ranging from 1,021 to $865 \mathrm{~m}$ a.s.I. (IPPUC, 2014). Located on the first plateau, Curitiba currently has 75 districts and is considered $100 \%$ urban. The population is $1,751,907$, constituting $54.3 \%$ of the population of the Metropolitan Region of Curitiba, which is composed of 29 municipalities, making it the eighth most populous metropolitan region in Brazil, with 3,502,790 inhabitants (estimated population in 2015 by IBGE), and it concentrates $31.37 \%$ of the total state population (COMEC, 2012).

According to Köppen, the Curitiba region is located in the climate context $\mathrm{Cfb}$, which is a mesothermal climate, wet and super humid, with no dry season, with cool summers and winters with frequent frosts and occasional snow events (CURITIBA, 2012). The city of Curitiba is inserted in the Atlantic Forest biome, in the ecoregion of the Araucaria Forest (Araucaria Forest) and Fields (Steppe). Considering the mapping done by the Municipal Environment, Curitiba has areas of forest in good condition, accounting for about 78 million square meters or $18 \%$ of the city. Of this total, about $75 \%$ are in private properties, located mainly in the neighborhoods of Santa Felicidade, Umbará and Barreirinha, and the other $25 \%$ are in public areas (CURITIBA, 2012). The fields (steppe) are practically suppressed, being found more continuously only in the surrounding municipalities. In Curitiba, only a few small remnants can still be seen on vacant lots, rare bottoms of valleys or backyards with uncovered soil (KERSTEN et al., 2014).

\section{Methodological Procedure}

Forty urban green areas (parks and public forests) were selected in order to carry out an economic analysis of the effects of such areas on the price of real estate, highlighting three other units: 1) Airumã Private Reserve of Natural Heritage Municipal; 2) Teresa Urban Ecological Station; and, 3) Green Area of the Presidente Getúlio Vargas Refinery - Repar, located in a mixed alluvial forest area (Table 1). The base data were the longitude and latitude coordinates of the perimeter of the parks and woods, the perimeters of the green areas (Airumã, Teresa Urban and Repar), prices and location of houses and apartments. The data of parks and public forests were obtained from the Planning Institute of Curitiba (IPPUC) and the houses were collected through research on real estate websites such as ImóvelWeb and Viva Real. The initial criterion adopted for collecting data on apartments and houses was, whenever possible, a maximum of 100 apartments and 100 houses for each of the 75 neighborhoods. Information was obtained on the structural characteristics of 2,832 apartments and 2,500 houses, detailing whether the location of the property was condominium or not, number of suites, rooms, garages, bathrooms and age of the property. On the other hand, neighborhood data for Curitiba's 75 neighborhoods, such as simple domicile index, homicide rate and population density were collected from the IPPUC website, while theft and robbery rates for the year 2016 of the 75 neighborhoods were provided by the Public Security Secretariat of the State of Paraná.

To calculate all the environmental variables, geographic coordinates of all the apartments and houses were collected through Google Earth. Lastly, with a view to the econometric analysis, the lowest Euclidean distance between the real estate and the perimeters of parks and public forests was calculated using Geoprocessing tools, especially ArcGIS software. Analyzing the variation of the type, quantity and quality of 
hedonic attributes in relation to the corresponding variation in the price of the property, it was possible to verify questions related to the implicit value, as well as their impact on the consumer and, consequently, their relation with the desire to pay for the ecosystem services generated by these areas (FREEMAN et al., 2014). The estimated effect also allows comparing different types of urban green areas with respect to their relative relevance and their implicit value, provided that different types of areas can be approached as distinct hedonic attributes.

Table 1: Data of the analyzed areas.

\begin{tabular}{|c|c|c|c|}
\hline & Airumã PRNHM & $\begin{array}{l}\text { Teresa } \\
\text { Ecological Station }\end{array}$ & $\begin{array}{l}\text { Repar (belongs to } \\
\text { the Presidente Getúlio } \\
\text { Vargas Refinery) }\end{array}$ \\
\hline Área & $28.500 \mathrm{~m}^{2}$ & $275.900 \mathrm{~m}^{2}$ & $92.000 \mathrm{~m}^{2}$ \\
\hline Location & $\begin{array}{l}\text { São João Neighborhood } \\
\text { (Regional Santa Felicidade) } \\
\text { portion north/northwest of } \\
\text { Curitiba }\end{array}$ & $\begin{array}{l}\text { Alto Boqueirão Neighborhood, } \\
\text { southeast portion of the city, near } \\
\text { the border with the city of São José } \\
\text { dos Pinhais }\end{array}$ & $\begin{array}{l}\text { Campo do Santana } \\
\text { Neighborhood, on the } \\
\text { border with the city of } \\
\text { Araucária (Tindiquera } \\
\text { Neighborhood) }\end{array}$ \\
\hline $\begin{array}{l}\text { Year of creation / } \\
\text { characteristic }\end{array}$ & $\begin{array}{l}\text { 2013, preserving a fragment of } \\
\text { Mixed Ombrophylous Forest in } \\
\text { middle and advanced stages of } \\
\text { succession (SOCIEDADE CHAUÁ } \\
\text { et al., 2013) }\end{array}$ & $\begin{array}{l}\text { 2016, Municipal Public } \\
\text { Conservation Unit, the only one to } \\
\text { protect the phytophysiognomy of } \\
\text { fields, associated with the Mixed } \\
\text { Rainforest Montana and Alluvial }\end{array}$ & $\begin{array}{l}{[1977], \text { presence of }} \\
\text { remnants of the Alluvial } \\
\text { Mixed Ombrophilous } \\
\text { Forest, in good condition } \\
\text { (BARDDAL et al., 2004) }\end{array}$ \\
\hline $\begin{array}{l}\text { Sociodemographic Profile } \\
\text { / Infrastructure* }\end{array}$ & Good quality & Good quality & Quality \\
\hline $\begin{array}{l}\text { Monthly household } \\
\text { income }\end{array}$ & $\begin{array}{l}\mathrm{R} \$ 5.139,76 \\
\text { (above the city average) }\end{array}$ & $\mathrm{R} \$ 2.370,95$ & $R \$ 1.713,44$ \\
\hline Green area index** & High, $540,53 \mathrm{~m}^{2}$ per inhabitant & Low, $27,42 \mathrm{~m}^{2}$ per inhabitant & Medium high, $255,27 \mathrm{~m}^{2}$ \\
\hline Demographic density & Low, of 10,72 inhabitant/ha & High, of 44,77 inhabitant/ha, & $\begin{array}{l}\text { Low, of } \\
\text { inhabitant/ha }\end{array}$ \\
\hline $\begin{array}{l}\text { Rate of homicides and } \\
\text { general occurrences (per } \\
100,000 \text { inhabitants) }\end{array}$ & 0,00 & $\begin{array}{l}\text { High, homicide rate of } 48.44 \text {, and } \\
\text { general occurrence of } 55.90 \text { (higher } \\
\text { than the general average of the } \\
\text { city). }\end{array}$ & $\begin{array}{l}\text { Medium high, homicide } \\
\text { rate and general } \\
\text { occurrence of } 15,01\end{array}$ \\
\hline
\end{tabular}

Note: ${ }^{*}=$ garbage collection, distribution of electricity and sanitary disposal.

** The general average of the city is $58 \mathrm{~m}^{2}$ /inhabitant

Source: IPPUC (2014).

In this paper, based on John (2014) and Votsis (2017), it was considered that the prices of apartments and houses depend on: (i) their structural characteristics; (ii) its accessibility or distance from the shopping center and services (CBD); (iii) their economic and social neighborhood characteristics such as: simple household index (IDS), homicide rate (TH), thefts and robbery rate (FTH); and (iv) their ecological amenities such as: proximity to public and private urban green areas, however conditioned by the distance from the commercial and service center (CBD), which justifies the linear terms $C^{*}$ DBP and C*DPP.

Therefore, the theoretical model of the hedonic price of urban real estate was represented by the following function: Price of the property $=\mathrm{F}$ (structural characteristics, accessibility to the shopping center and services - $\mathrm{CBD}$, neighborhood variables, ecological amenities variables). Parks, forests and remnants of private vegetation have the potential to generate ecosystem services with effects of overflows or positive or negative externalities on the prices of apartments and houses in their surroundings.

In order to capture these interactions, a Spatial Data Exploratory Analysis (AEDE) of Curitiba real estate prices was initially performed, based on the 'Moran's I Global univariate and bivariate', and the 'Moran's I Univariate Site or LISA'. Afterwards, the methodology of spatial econometrics was applied. In order 
to implement the AEDE it is necessary to adopt a spatial weighting matrix (W). According to Almeida (2012), this is a square matrix of order $n$ by $n$, whose elements denote the degree of spatial connection between real estate prices under analysis following some criterion of proximity.

Following Votsis (2017), in the specification of the spatial weighting matrix was adopted as proximity criterion the contiguity with tower-type convention, but with order of contiguity equal to 2 for apartment prices and 1 for house prices, different from article by Votsis (2017), which adopted a contiguity order equal to 1 to model apartment prices. The criterion of proximity is based on contiguity, assuming that contiguous regions have a stronger interaction than noncontiguous ones. This interaction may both stimulate the spreading and the repulsion of the selected variable (in the case of this research, the price variation of apartments and houses in Curitiba in the year 2017).

Thus, the element $w_{i j}$ of the spatial weighting matrix (W) will have value equal to 1 when two properties are contiguous and 0 , otherwise. In the AEDE implementation, the global spatial autocorrelation tests were used in a univariate and bivariate context, trying to find out if the values of an observed variable (ecological variable) in a given property have a systematic relation with the values of another variable observed (price variation) in neighboring properties. In formal terms, it is possible to calculate the Moran's I statistic for two different variables, $y$ and $x$ (1). Positive and negative values of the bivariate Moran's I denote spatial concentration and dispersion, respectively.

$$
\mathrm{I}^{\mathrm{yx}}=\frac{\mathrm{n}}{\sum_{\mathrm{i}} \sum_{\mathrm{j}} \mathrm{w}_{\mathrm{ij}}} \frac{\sum_{\mathrm{i}} \sum_{\mathrm{j}}\left(\mathrm{x}_{\mathrm{i}}-\overline{\mathrm{x}}\right) \mathrm{w}_{\mathrm{ij}}\left(\mathrm{y}_{\mathrm{i}}-\overline{\mathrm{y}}\right)}{\sum_{\mathrm{i}}\left(\mathrm{x}_{\mathrm{i}}-\overline{\mathrm{x}}\right)^{2}}
$$

On the other hand, in the particular case of univariate Moran's I Global statistic, the variable is $x_{i}$ and $\mathrm{x}_{\mathrm{j}}$, where: $\mathrm{x}_{\mathrm{i}}$ represents the price of a given spatial unit (apartment or house), while: $\mathrm{x}_{\mathrm{j}}$ represents the prices of other units' space, ie the prices of its neighbors in its surroundings. The univariate or bivariate Moran's I Global statistic does not detect the presence of structural heterogeneity and distinct spatial regimes in spatial data such as data from the real estate market of the city of Curitiba.

Thus, in AEDE, it is inexorable to use the Moran's I Local statistic, which decomposes the global autocorrelation indicator into the local contribution of each observation into four categories: high-high (AA), low-low (BB), high-low ( $A B$ ) and low-high (BA), each individually corresponding to a quadrant in the dispersion diagram of Moran (ALMEIDA, 2012). The presence of AA and BB clusters with statistical significance in the real estate market implies that in addition to the spatial dependence on real estate prices, there is statistical evidence of spatial heterogeneity: in more "noble" neighborhoods of the city, certain properties with above-average prices are surrounded by real estate with above-average prices; and in neighborhoods generally on the outskirts of the city, certain properties with below average prices are surrounded by properties also priced below average.

\section{Spatial Hedonic Regression Models of Real Estate Prices}

As for the functional form of the price equation of hedonic real estate, in the economic literature there are several ways of presenting the price model, provided that the theories do not define the functional 
form nor the variables that should be used to estimate the price equation. The use of spatial regression models is considered one of the best options to provide insights into issues that notably involve urban planning. This is because they have the ability to address estimation problems that are characteristic of spatial data analysis and hedonic data sets (GERKMAN, 2012; VOTSIS, 2017).

One of the widely used possibilities is the adoption of log-linear regression functions, which was used, although some authors claim that the hedonic price function is not linear, the great majority of hedonic studies have used simple functional forms, such as: linear, log-linear, or log-log forms (MEl et al. 2018). In model 2 (2), we sought to identify the impact of the ecosystem services (amenities) generated by the remaining vegetation in the green areas Airumã, Repar and Teresa Urban on the price of apartments and houses in Curitiba (Table 2):

$$
\begin{aligned}
\text { LnPImovel }= & \beta_{0}+\beta_{1} \mathrm{CF}_{\mathrm{i}}+\beta_{2} \mathrm{~S}_{\mathrm{i}}+\beta_{3} \mathrm{G}_{\mathrm{i}}+\beta_{4} \mathrm{Q}_{\mathrm{i}} \\
& +\beta_{5} \mathrm{~B}_{\mathrm{i}}-\beta_{6} \mathrm{I}_{\mathrm{i}}-\beta_{7} \mathrm{C}_{\mathrm{i}} \\
& -\beta_{8} \mathrm{IDS}_{\mathrm{j}}-\beta_{9} \mathrm{TH}_{\mathrm{j}}-\beta_{10} \mathrm{TFH}_{\mathrm{j}}-\beta_{11} \mathrm{DPP}_{\mathrm{i}}-\beta_{12} \mathrm{DBP}_{\mathrm{i}}-\beta_{13} \mathrm{DA}_{\mathrm{i}}+\beta_{14} \mathrm{DT}_{\mathrm{i}} \\
& +\beta_{15} \mathrm{DR}_{\mathrm{i}}+\beta_{16} \mathrm{C}_{\mathrm{i}} * \mathrm{DPP}_{\mathrm{i}}+\beta_{17} \mathrm{C}_{\mathrm{i}} * \mathrm{DBP}_{\mathrm{i}}+\beta_{18} \mathrm{AT}_{\mathrm{i}}+\beta_{18} \mathrm{AU}_{\mathrm{i}}+\mathrm{u}_{\mathrm{i}}
\end{aligned}
$$

Table 2: Expected signal of analyzed variables for prices of apartments and houses in Curitiba

\begin{tabular}{|l|l|l|}
\hline Variable & Description & Signal \\
\hline $\mathrm{Q}$ & Number of bedrooms & Positive \\
\hline S & Number of suites & Positive \\
\hline B & Number of bathrooms & Positive \\
\hline G & Number of garages & Positive \\
\hline AT & Total area in square meters & Positive \\
\hline AU & Useful area in square meters & Positive \\
\hline CF & Variable assumes value 1, if the property is in closed condominium & Positive \\
\hline I & Age of property in years & Negative \\
\hline C+DCBD & Distance to shopping center and services in Curitiba in meters (*) & Negative \\
\hline DBP & Distance from nearest main forest in meters & Negative \\
\hline C*DBP & Distance in meters of CBD multiplied by DBP & Positive \\
\hline DPP & Distance from the nearest park in meters & Negative \\
\hline C*DPP & Distance in meters of CBD multiplied by DPP & Positive \\
\hline DA & Distance in meters of the property of the remaining vegetation Airumã & Negative \\
\hline DT & Distance in meters of the property of the remnant of vegetation Teresa Urban & Positive \\
\hline DR & Distance in meters of the property of remnant of vegetation Repar & Positive \\
\hline DA10000 & DA10000 assumes value 1, if the property is up to 10,000 meters from Airumã & Negative \\
\hline DA+10000 & Assumes value 1, if the property is more than 10,000 meters from Airumã & Negative \\
\hline DT5000 & Assumes value 1 if the property is situated up to 5,000 meters from Teresa Urban & Positive \\
\hline DR5000 & Assumes value 1, if the property is up to 5,000 meters from Repar & Positive \\
\hline TH & Rate of homicide in the neighborhood & Negative \\
\hline TFR & Theft and robbery rate in the neighborhood & Negative \\
\hline DP & Inhabitants per square meter in the neighborhoods of Curitiba & Negative \\
\hline IDS & Simple household index & Negative \\
\hline Note: $*$ CBD & has been defined as the pint in downtown Curiba, intersection of Streets XV de Novembro and Marechal & \\
\hline
\end{tabular}

Note: $\left({ }^{*}\right)$ CBD has been defined as the point in downtown Curitiba, intersection of Streets XV de Novembro and Marechal Floriano Peixoto, one of the highest densities of commercial and service establishments.

Estimates of model 2 for prices of apartments and houses were performed using spatial econometrics methodology, given the existence of spatial dependence. In this methodology, the first step is the decision on the best spatial model: (i) spatial lag model (SAR) or (ii) autoregressive spatial error model (SEM). In order to detect the type of spatial autocorrelation and to define the most appropriate spatial model, the Lagrange Multiplier (ML) tests were considered. The ML $\rho$ test observes the spatial lag in the endogenous variable, in 
the real estate price case (null hypothesis of $H_{0}: \rho=0$ ), while the $\mathrm{ML} \lambda$ test observes the spatial autocorrelation in the error (null hypothesis $H_{0}: \lambda=0$ ). Thus, five steps were taken to identify the most appropriate econometric model: (i) the model was estimated by the MQO; (ii) the presence of spatial autocorrelation was tested through the ML $\rho$ and ML $\lambda$ statistics; (iii) if both tests were not significant, the model would not show spatial autocorrelation; (iv) if both tests were significant, it would be necessary to calculate robust versions of these tests and estimate the most significant model; $(v)$ if only one of the tests were significant, this would be the most appropriate model. Considering the results of ML $\rho$ and ML $\lambda$, the most suitable econometric model for the model (2) consists of spatial lag or SAR. In the case of SAR, it may be expressed by (3):

$$
y=\rho W y+X \beta+\varepsilon .
$$

Where: $y$ is the dependent variable; $\rho$ is the spatial autoregressive coefficient; Wy is a $n \times 1$ vector of spatial lags for the dependent variable; $X$ is the matrix of explanatory variables; $\beta$ is a vector of parameters and $\varepsilon$ is the term error. The models of type (3) indicate that a change in the explanatory variable in a locality will affect not only the locality itself by the direct effect but can affect the value of the dependent variable in all the localities through the indirect effects (ALMEIDA, 2012). These indirect effects are interpreted as spatial overflows.

The Spatial Error Model (SEM) model is expressed by (4): $\mathrm{y}=\mathrm{X} \beta+\xi$ Where: $\xi=\lambda W \xi+\varepsilon$.

In that: the parameter $\lambda$ is the spatial autoregressive error that accompanies the $W \xi$ lag that seeks to capture spatial dependence in the residuals, while, in turn, the parameter $\xi$ represents the error term.

In this model the spatial dependence in (4) is revealed in the error term, emphasizing that the errors related to any observation are a mean of the errors in the localities of the envelope, added of a random component. Thus, expression (4) indicates that the effects on the dependent variable do not result only from the shock (denoted by the term of error) of a locality of the city, but from the overflowing shocks from other neighboring points of the urban space.

Another model of spatial regression refers to the spatial-lagged model of the endogenous variable and spatial dependence in the error term (SARMA): $\mathrm{y}=\rho \mathrm{Wy}+\mathrm{X} \beta+\xi(5)$, where: $\xi=\lambda W \xi+\varepsilon$. In that the parameter $\rho$ is the coefficient that captures the spatial interactions, $W y$ is the spatial weights matrix chosen and; $\mathrm{X}$ is the vector containing the explanatory variables of the hedonic function. For the choice between the SAR, SEM and SARMA models the same procedures were applied, based on the Lagrange Multiplier tests. Estimates that showed a violation of the econometric assumptions (heteroscedasticity and non-normality of regression residuals) were re-estimated with the correction of these problems. In order to control the heteroskedasticity, its correction was used for White's robust matrix, whereas for the absence of normality in the errors, the generalized moments method was used, since it depends on the assumption of the normality of the errors (ALMEIDA, 2012). Anselin-Kelijian spatial dependence test was used to verify if the spatial dependence was adequately controlled.

Finally, all estimates of SAR, SEM and SARMA models were implemented in GeoDa ${ }^{\mathrm{TM}}$ SPACE free software, while all the graphs and calculations required for the AEDE, such as the univariate and bivariate Moran's I Global and Moran's I Local, were implemented in Open GeoDa ${ }^{\mathrm{TM}}$. The explanatory variables of the econometric models of hedonic prices of apartments and houses were summarized in Table 2 . The expected 
positive sign means that the explanatory variable should contribute to the increase of the price of the apartment or house, while the negative sign implies that the explanatory variable should contribute to the reduction of the price of apartments and houses.

\section{RESULTS}

\section{Price of real estate and ecological variables}

Figure 1 shows a negative linear correlation between the price of apartments and houses in relation to the distance of woods and parks, indicating that the closer an apartment or house is to the forest or park in Curitiba, the greater is its selling price. This positive relationship between the price of real estate and the proximity of green areas is highly substantiated in the international literature (CZEMBROWSKI et al., 2016; PERINO et al., 2014; SIRIWARDENA et al., 2016), the closer a residence is to a green area valued within the urban context, the higher its selling price.

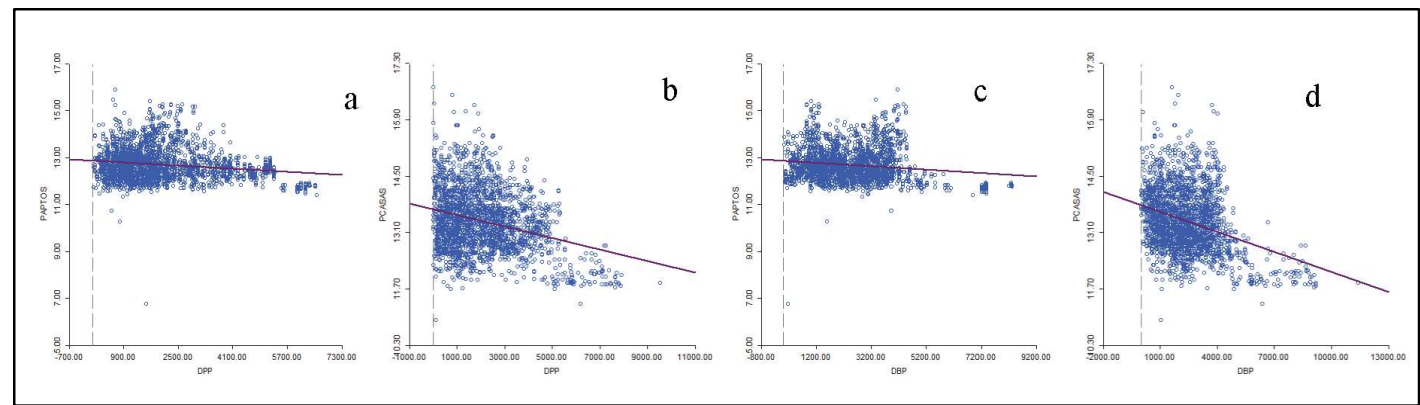

Figure 1: Relation between the distance to public parks ( $a$ and $b$ ) and public forests ( $c$ and $d$ ) and apartment/house prices in Curitiba.

Figure 2 shows the presence of bivariate global spatial dependence between the price of apartments and houses and the distances of the properties from the woods and parks, indicating that the closer a property (less than the average distance) is located of a forest or a park, the greater its price (above average). The bivariate autocorrelation between real estate prices and the distances of forests and public parks is negative (positive effect) and significant at the $1 \%$ level.

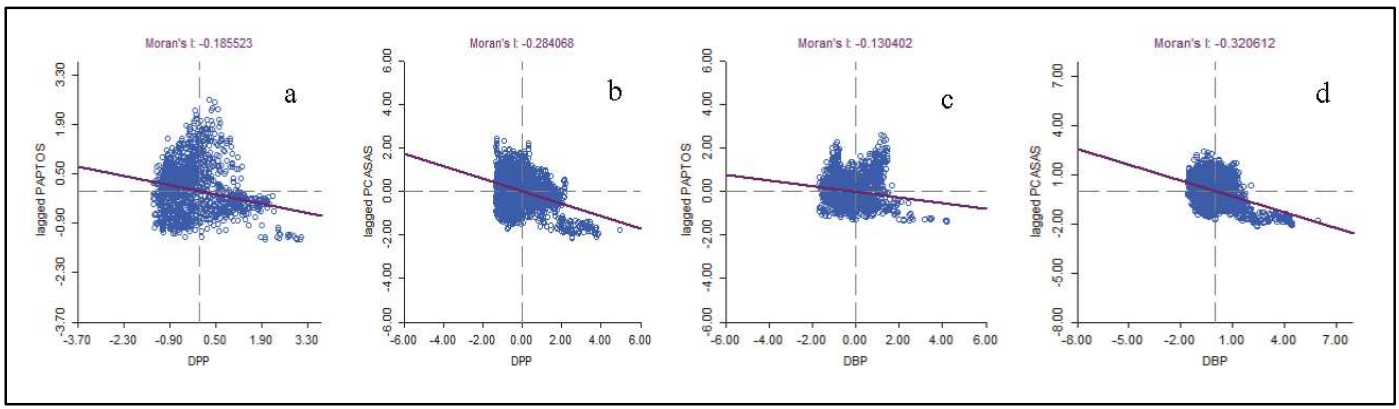

Figure 2: Spatial autocorrelation of the bivariate global Moran's I between the distance to public parks (a and b) and public forests ( $c$ and $d$ ) and apartment/house prices in Curitiba.

In the measurement of the variables in relation specifically to the Airumã PRNHM, Figure 3 characterizes the presence of linear negative correlation and global bivariate global spatial dependence between the price of apartments and houses and the distances of the properties of this fragment of 
vegetation. The closer a property is to Airumã, the higher will be the price of this property, as well as the properties located in or around its surroundings and vice-versa. The bivariate global autocorrelation between real estate prices and distances from the Airumã PRNHM is negative (positive effect) and significant at 1\%.

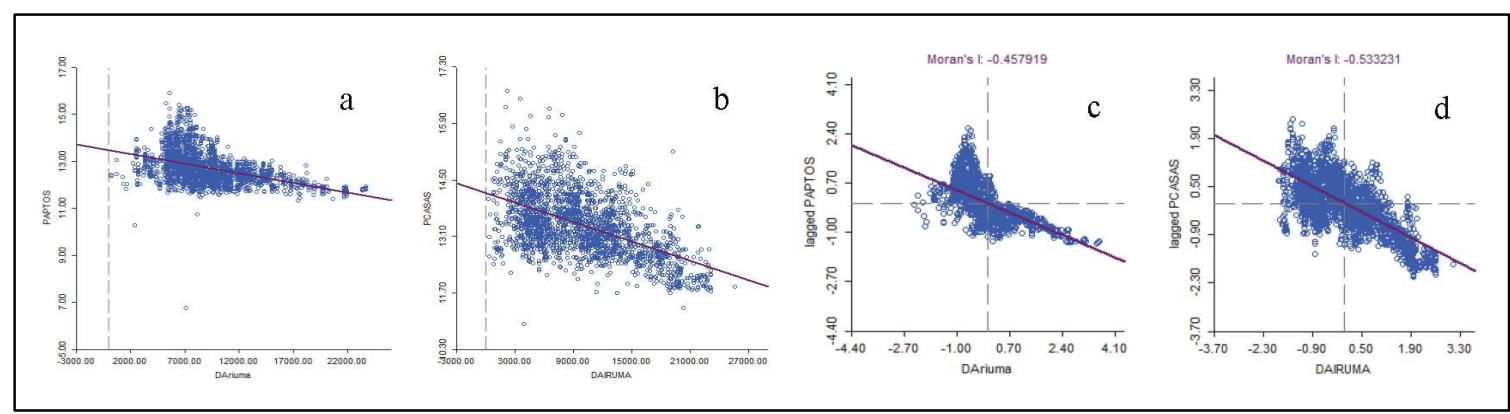

Figure 3: Relation between the distance to the Airumã PNHR and apartment/house prices in Curitiba (a and b) and bivariate global spatial autocorrelation between Airumã and apartment/house prices in Curitiba (c and d).

In the measurement of the variables in relation to the Teresa Urban Ecological Station (Figure 4) and the urban green area of Repar (Figure 5), there is a positive linear correlation and a positive bivariate global spatial dependence between the price of apartments and houses and the distance from the properties of the conservation unit. The closer a property is located to these units, the lower its price, as well as the properties located in or around its vicinity. Moran's I's bivariate global autocorrelation between real estate prices and the distances of both the Teresa Urban Ecological Station and the urban green area of Repar is positive (negative effect) and significant at $1 \%$.

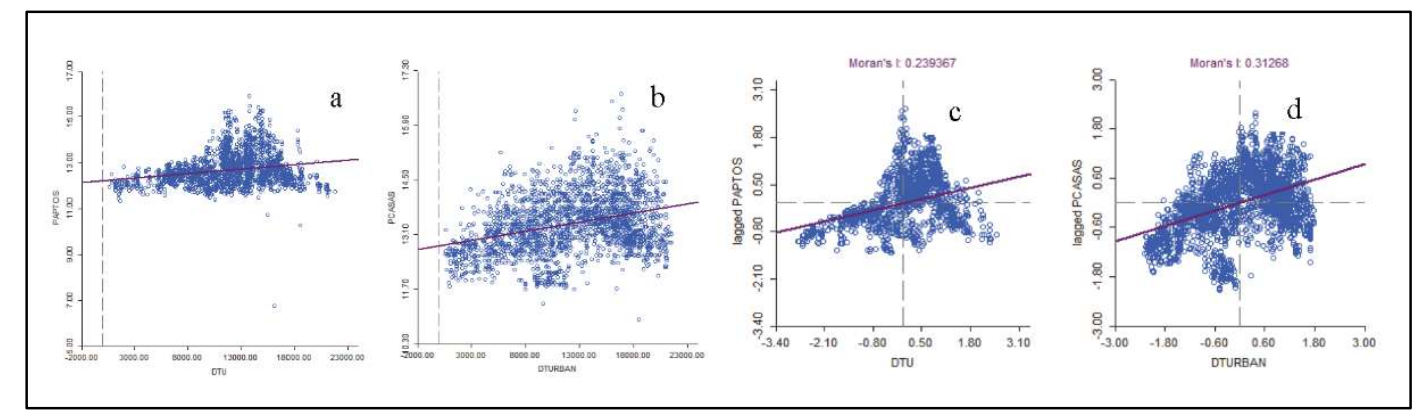

Figure 4: Relation between the distance to the Teresa Urban Ecological Station and apartment/house prices in Curitiba (a and b) and bivariate global spatial autocorrelation between the Teresa Urban Ecological Station and apartment/house prices in Curitiba (c and d).

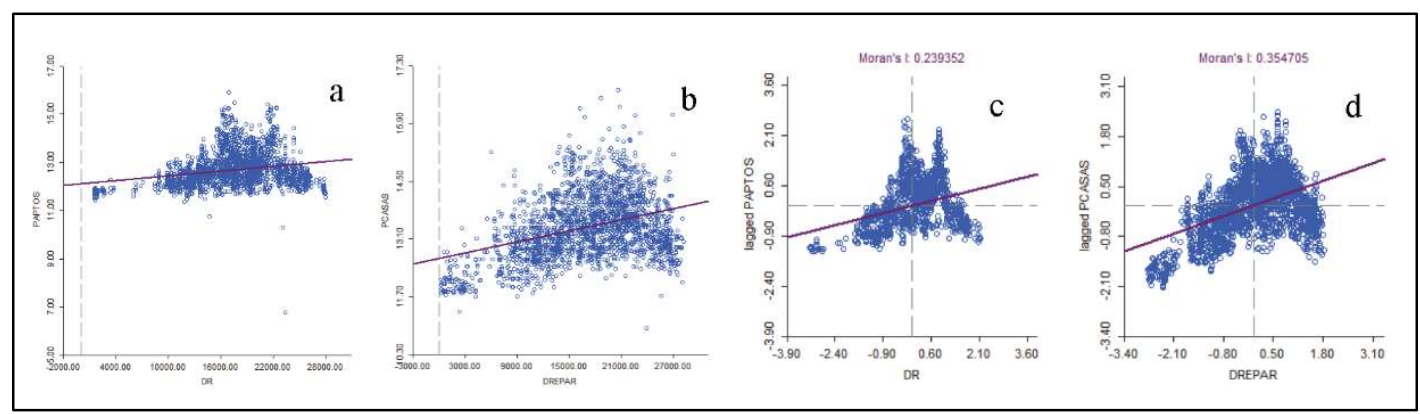

Figure 5: Relation between the distance to the Repar green area and apartment/house prices in Curitiba (a and b) and bivariate global spatial autocorrelation between the Repar green area and apartment/house prices in Curitiba ( $c$ and $d$ ).

\section{Prices of real estate and the distance from the shopping center and services}

Figure $6(\mathrm{a}$ and $\mathrm{b})$ shows the positive spatial dependence between the price of apartments and houses, 
in their neighborhood, at a significance level of $1 \%$. An apartment or house with above average price has in its surroundings apartments or houses with prices above average or vice-versa.

Figure 6 (c and d), in turn, reports the Moran's I local spatial autocorrelation, characterizing the presence of a monocentric city. That is, there is only one high-high cluster, consisting of 685 apartments and 400 houses. In both real estate cases, the highest spatial distribution is concentrated around the shopping and service center located in the north, while apartments $(1,047)$ and houses $(451)$ of lower prices (below the average price) are concentrated in the neighborhoods in the southern and peripheral parts of the territory, whose supply and quality of infrastructure and urban services are below those of the northern portion. The LISA agglomerate map evidences that the distance relationship of the property and the shopping center and services of Curitiba has a significant and negative effect on the prices of apartments and houses in Curitiba. The further away a property is from the CBD, the lower its selling price will be. It also reveals that the spatial distribution of apartment prices is more concentrated in the region close to the CBD than the spatial distribution of house prices of Curitiba in the samples collected.

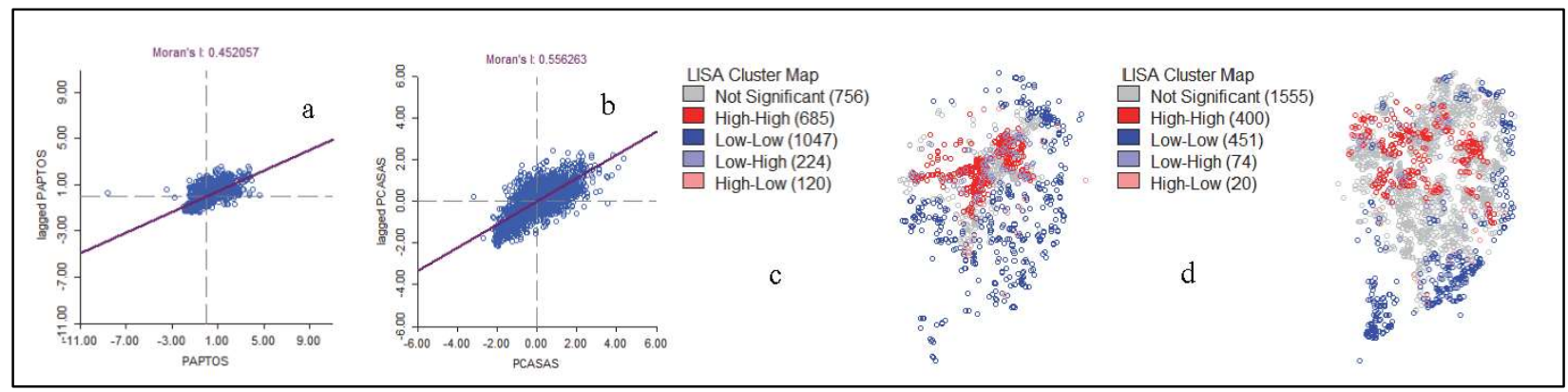

Figure 6: Univariate global spatial autocorrelation in prices of apartments (left) and houses (right) in Curitiba e and Map of spatial dependence clusters for prices of apartments (c) and houses (d) in Curitiba.

This occurs due to the fact that the zoning law of the city of Curitiba motivates collective housing buildings with a higher number of floors along the important structural routes (structural axes) that connect neighborhoods to the city center. These roads are targeted by real estate agencies because they have infrastructure for consolidated mobility, including Bus Rapid Transit (BRT). Such routes also encourage the mixed use of the land, such as the commercial use of the ground floor of buildings. Traditionally, higher standard buildings have been concentrated both along and around where such infrastructure is offered. Higher-value single-family homes, however, appear on the map in areas close to the structural axes (also addressing market forces subject to land use and land use legislation). The presence of high-value houses in regions near the border of the city in the extreme north and northwest is also noted, where several condos of luxury houses were consolidated by the offer of extensive land combined with the presence of remnant vegetation, according to the map of clusters of spatial dependence of apartment prices and houses of Curitiba (c and d) exposed in Figure 6.

\section{Econometric results}

In Table 3, model 1 sought to estimate the overall effect of the three remnants of native vegetation on the price of the 2,832 apartments in the year 2017. It is observed that the estimated coefficient of the 
ecological variable DA is negative (positive effect) and this variable is significant at the $5 \%$ level, while the DR, DT, DR10000 and DT10000 variables are not significant at the $10 \%$ level. It can be inferred that Airumã PRNHM has a positive and significant effect, whereas Repar and Teresa Urban have negative effects and are not significant on apartment prices.

In models 2 and 3 , we tried to test whether the positive or negative effect of these three remnants of native vegetation are evidenced in their surroundings. It can be inferred that the remainder of native vegetation Airumã exerts a greater effect or impact on the prices of apartments located closer to their surroundings, since the effect of the ecological variable D10000 is positive and significant in model 2 and the effect of the ecological variable $D+10000$ is negative and significant in model 3 . Regarding the amplitude of the effects of the Repar and Teresa Urban areas, probably due to sample limitations, they are not conclusive.

The variable DCBD, which is the distance to the center of commerce and services, representing accessibility to employment, commerce and services, has an expected and negative signal (positive effect): apartments with a location closer to the CBD have higher market value. The estimate validated the assumptions of a CBD gradient on the marginal effect of parks and forests on apartment prices. An increasing distance from a park reduces prices in the center of the city or, on the contrary, decreasing the distance of an apartment from the park in the central part of the city increases its price with the effect gradually declining when the distance to the CBD increases. However, the increasing distance of forests decreases the price in suburban neighborhoods or, on the contrary, reducing the distance of a forest apartment on the outskirts of the city increases its price.

In sum, the ecological variables such as distance from parks (DPP) and public forests (DBP) have a positive effect on the price of apartments, but conditional on the CBD distance. In Table 3, to estimate the amplitude of the effect of the three remnants of native vegetation (Airumã, Teresa Urban and Repar), three models of hedonic regression with spatial lag in the appraised apartment prices were estimated. As for the neighborhood variables, these also presented the expected signal: the simple domicile index (IDS) has a negative and significant effect, as well as the disasters of urban violence such as theft and robbery rate (TFR) and the homicide rate (TH) present negative and significant effect.

Table 3: Estimate of spatial lag in apartment prices in Curitiba (2832 apartments)

\begin{tabular}{|c|c|c|c|}
\hline Variable & $\begin{array}{l}\text { Model } 1 \\
\text { Coef. (Default Error) }\end{array}$ & $\begin{array}{l}\text { Model } 2 \\
\text { Coef. (Default Error) }\end{array}$ & $\begin{array}{l}\text { Model } 3 \\
\text { Coef. (Default Error) }\end{array}$ \\
\hline AU & $0.0016098(0.0005100)^{* * *}$ & $0.0016026(0.0005060)^{* * *}$ & $0.0016026(0.0005060)^{* * *}$ \\
\hline B & $0.1325159(0.0170985)^{* * *}$ & $0.1316419(0.0169903)^{* * *}$ & $0.1316419(0.0169903)^{* * *}$ \\
\hline G & $0.2283131(0.0189819)^{* * *}$ & $0.2288077(0.0188386)^{* * *}$ & $0.2288077(0.0188386)^{* * *}$ \\
\hline I & $-0.0067392(0.0008028)^{* * *}$ & $-0.0068186(0.0008028)^{* * *}$ & $-0.0068186(0.0008028)^{* * *}$ \\
\hline Q & $0.0748202(0.0115027)^{* * *}$ & $0.0750487(0.0113280)^{* * *}$ & $0.0750487(0.0113280)^{* * *}$ \\
\hline$S$ & $0.1212326(0.0159844)^{* * *}$ & $0.1222375(0.015953)^{* * *}$ & $0.1222375(0.0159530)^{* * *}$ \\
\hline DCBD & $-0.0220784(0.0042145)^{* * *}$ & $-0.0218953(0.0039667)^{* * *}$ & $-0.0218953(0.0039667)$ \\
\hline DBP & $0.0000323(0.0000133)^{* *}$ & $0.0000322(0.0000131)^{* *}$ & $0.0000322(0.0000131)^{* *}$ \\
\hline C*DBP & $-0.0000029(0.0000013)^{* *}$ & $-0.0000031(0.0000012)^{* *}$ & $-0.0000031(0.0000012)^{* *}$ \\
\hline DPP & $-0.0000234(0.0000104)^{* *}$ & $-0.0000201(0.0000110)^{*}$ & $-0.0000201(0.0000110)^{*}$ \\
\hline C*DPP & $0.0000033(0.0000012)^{* * *}$ & $0.0000031(0.0000013)^{* *}$ & $0.0000031(0.0000013)^{* *}$ \\
\hline DA & $-0.0000049(0.0000025)^{* *}$ & & \\
\hline DR & Non-significant & & \\
\hline DT & Non-significant & & \\
\hline DA10000 & & $0.0438934(0.0160042) * * *$ & \\
\hline
\end{tabular}




\begin{tabular}{|c|c|c|c|}
\hline Variable & $\begin{array}{l}\text { Model } 1 \\
\text { Coef. (Default Error) }\end{array}$ & $\begin{array}{l}\text { Model } 2 \\
\text { Coef. (Default Error) }\end{array}$ & $\begin{array}{l}\text { Model } 3 \\
\text { Coef. (Default Error) }\end{array}$ \\
\hline DT10000 & & Non-significant & Non-significant \\
\hline DR10000 & & Non-significant & Non-significant \\
\hline$D A+10000$ & & & $-0.0438934(0.0160042)^{* * *}$ \\
\hline IDS & $-0.1347455(0.0285151)^{* * *}$ & $-0.1216295(0.0285257) * * *$ & $-0.1216295(0.0285257)^{* * *}$ \\
\hline $\mathrm{TH}$ & $-0.0002540(0.0001480)^{*}$ & $-0.0003077(0.0001494)^{* *}$ & $-0.0003077(0.0001494)^{* *}$ \\
\hline TFR & $-0.0000071(0.0000034) * *$ & $-0.0000062(0.0000034)^{*}$ & $-0.0000062(0.0000034)^{*}$ \\
\hline W_PAPTOS & $0.2037902(0.0223551)^{* * *}$ & $0.203689(0.0212144) * * *$ & $0.2036890(0.0212144)^{* * *}$ \\
\hline
\end{tabular}

There is also empirical evidence that apartment price behavior can be estimated using hedonic spatial lag regression models. The marginal effects of green areas on prices may vary in different parts of the city (VOTSIS, 2017), and may exert null behavior in some places (CHO et al., 2011). The spatial 'lag' of the endogenous variable apartment price (W_PAPTOS) is significant at the $1 \%$ level in all three models. The AnselinKelejian test (A-K) also shows that there is no spatial dependence on regression residuals at a significance level of $10 \%$.

In models 1,2 and 3 the Anselin-Kelejian test statistics are respectively 0.05, 0.157 and 0.157 , with empirical significance levels of $82.27 \%, 69.23 \%$ and $69.23 \%$. The three hedonic spatial regression models present good adjustment to the price data of apartments with spatial determination coefficients equal to $83.98 \%, 84 \%$ and $84 \%$, respectively. In Table 4, the results of the estimations of spatial hedonic regression models of the prices of 2,500 houses are reported. The results also show that the structural characteristics present a signal consistent with the evidence contained in the literature, that is, they exert the greatest influence within the price function (WÜSTEMANN et al., 2017).

However, there is a change in the order of relevance in relation to apartment prices, since the main structural characteristics in determining the price of houses are the suite, the condominium, the number of rooms, the number of garages, the number of bathrooms, the floor area and the total area. An additional suite increases the price of the house by an average of $10.4 \%$. On the other hand, the age of the house has a significant negative effect on its price level, the total area is also significant in determining prices of houses in Curitiba. One possible explanation for the non-empirical relevance of the age of houses in determining their prices is the lack of data on this variable in the real estate sites surveyed in the sample of 2,500 houses.

In turn, the variable DCBD, which is the distance to the center of trade and services representing the accessibility to employment and to trade and services, has an expected and negative sign (positive effect) (not reported in Table 3), but not was significant in the determination of house prices of the sample. This result can be justified by the possibly distinct profile of home and apartment buyers. The buyer of houses has, in general, greater purchasing power, means of transportation alternative to public transportation and a preference for residences far from the CBD to avoid their negative side effects, such as noise, atmospheric and environmental pollution (MEl et al., 2018).

Table 4: Estimate of spatial lag in houses prices in Curitiba (2500 houses).

$\begin{array}{llll}\text { Variable } & \text { Model 1 } & \begin{array}{l}\text { Model 2 } \\ \text { Coef. (Default Error) }\end{array} & \begin{array}{l}\text { Model 3 } \\ \text { Coef. (Default Error) }\end{array} \\ \text { CF } & \text { Coef. (Default Error) } & 0.1005386(0.0180318)^{* * *} & 0.1006689(0.0180328)^{* * *} \\ \text { AT } & 0.1024609(0.0181022)^{* * *} & 0.0000617(0.0000210)^{* * *} & 0.0000617(0.000021)^{* * *}\end{array}$




\begin{tabular}{|c|c|c|c|}
\hline Variable & $\begin{array}{l}\text { Model } 1 \\
\text { Coef. (Default Error) }\end{array}$ & $\begin{array}{l}\text { Model } 2 \\
\text { Coef. (Default Error) }\end{array}$ & $\begin{array}{l}\text { Model } 3 \\
\text { Coef. (Default Error) }\end{array}$ \\
\hline$A U$ & $0.0016903(0.0002946)^{* * *}$ & $0.0016945(0.0002947 * * *$ & $0.0016949(0.0002948)^{* * *}$ \\
\hline B & $0.0345300(0.0072356)^{* * *}$ & $0.0341704(0.0072342)^{* * *}$ & $0.0341583(0.007235)^{* * *}$ \\
\hline G & $0.0399673(0.0080218)^{* * *}$ & $0.0394168(0.0079941)^{* * *}$ & $0.0394280(0.0079958)^{* * *}$ \\
\hline$Q$ & $0.0441580(0.0121459)^{* * *}$ & $0.0448113(0.0122279)^{* * *}$ & $0.0448194(0.0122280)^{* * *}$ \\
\hline S & $0.1035905(0.0128000)^{* * *}$ & $0.1036078(0.0127402)^{* * *}$ & $0.1035589(0.0127438)^{* * *}$ \\
\hline DBP & $-0.0000136(0.0000056)^{* *}$ & $-0.0000144(0.0000056)^{* * *}$ & $-0.0000144(0.000005)^{* * *}$ \\
\hline DPP & $0.0000298(0.0000083)^{* * *}$ & $0.0000237(0.0000083)^{* * *}$ & $0.000023(0.0000083)^{* * *}$ \\
\hline C*DPP & $-0.0000018(0.0000006)^{* * *}$ & $-0.0000011(0.0000006)^{*}$ & $-0.0000011(0.0000006)^{*}$ \\
\hline DA & $-0.0000100(0.0000020)^{* * *}$ & & \\
\hline DR & Non-significant & & \\
\hline DT & Non-significant & & \\
\hline DA10000 & & $0.0627395(0.0182433)^{* * *}$ & \\
\hline DT5000 & & $-0.0750324(0.0230368) * * *$ & $-0.075205(0.0230346)^{* * *}$ \\
\hline DR5000 & & $-0.1854439(0.0557295)^{* * *}$ & $-0.1856805(0.055766)^{* * *}$ \\
\hline$D A+10000$ & & & $-0.0627237(0.0183173) * * *$ \\
\hline IDS & $-0.1584124(0.0299631) * * *$ & $-0.1655399(0.0298583)^{* * *}$ & $-0.165829(0.0298353)^{* * *}$ \\
\hline $\mathrm{TH}$ & $-0.0004896(0.0002298)^{* *}$ & Non-significant & Non-significant \\
\hline TFR & Non-significant & $-0.0000105(0.0000053)^{* *}$ & $-0.0000105(0.0000053)^{* *}$ \\
\hline W_PCASA & $0.2871985(0.0388321)^{* * *}$ & $0.2878640(0.0393786)^{* * *}$ & $0.2874344(0.0394177)^{* * *}$ \\
\hline
\end{tabular}

The estimate also validated the assumptions of a CBD gradient in the marginal effect of parks and forests on house prices, but with differences in the location of the generation of positive externalities of these green areas. Increasing distance from a park or grove reduces house prices in suburban neighborhoods and vice-versa, with the effect gradually declining as the distance to the CBD decreases (VOTSIS, 2017). Thus, it is understood that the effect of parks on the price of houses is not constant in urban space. The increasing forest distance decreases the price of houses in neighborhoods in the central region and in the outskirts of Curitiba, which can lead to different price effects. In sum, the ecological variable of distance to parks (DPP) and forests (DPF) has a positive effect on the price of apartments while it is conditioned to the distance of the CBD.

In order to verify the amplitude of the effect of the three remnants of native vegetation (Airumã, Teresa Urban and Repar), three models of hedonic regression with spatial lag in house prices were estimated. In model 1 we try to estimate the overall effect of the three areas on the price of the 2,500 houses in the year 2017. It is verified that the estimated coefficient of the ecological variable DA is negative (positive effect) and this variable is significant at the level of $1 \%$, while the DR and DT variables are not significant at the $10 \%$ level. It can be inferred that PRNHM Airumã has a positive and significant effect, while the negative effects of Repar and Teresa Urban are not significant on house prices.

In models 2 and 3 we tried to test whether there are positive or negative effects of the presence of these three green areas. It can be inferred that the remainder of native vegetation Airumã exerts a greater effect or impact on the prices of nearest houses located in their surroundings, since the effect of the ecological variable D10000 is positive and significant in model 2 and the effect of the ecological variable D+10000 is negative and significant in model 3. It can also be inferred that the effects of the Repar and Teresa Urban areas exert a more negative and significant effect on the prices of houses located closer to their surroundings: DT5000 and DR5000 have negative coefficients at the significance level of $1 \%$.

The neighborhood variables also had the expected signal: the simple domicile index (IDS) had a 
negative and significant effect in all three models, while the disasters of urban violence, such as robbery and robbery (TFR), had a negative and significant effect on model 2 and 3, and the homicide rate (TH) has a negative and significant effect only in model 1 . There is empirical evidence that house price behavior can be estimated by spatial lagged hedonic regression models. The spatial 'lag' of the endogenous house price variable (W_PCASA) is significant at the $1 \%$ level in all three models. The Anselin-Kelejian test (A-K) also shows that there is no spatial dependence on regression residuals at the significance level of $10 \%$ in the models. Likewise, the statistics of said test are respectively $0.616,1.272$ and 1.261 in the cited models, with significance levels of $43.26 \%, 25.94 \%$ and $26.15 \%$. The three spatial hedonic regression models present good adjustment to house price data with spatial determination coefficients equal to $81.9 \%, 82.1 \%$ and $82.1 \%$, respectively.

\section{DISCUSSION}

The importance of green areas and green structures for the sustainable development of cities is undeniable. Likewise, the benefits they provide also reflect the prices of real estate and higher land (WÜSTEMANN et al., 2017). Similarly, recent research shows that green urban areas may have different impacts on real estate prices (LARSON et al., 2013). The results of the Spatial Data Exploratory Analysis (AEDE) and estimates of spatial hedonic regression models corroborate that parks and forests have a positive and significant effect on the price of apartments and houses, but are conditioned by distance from the $\mathrm{CBD}$, to be indifferent beyond the boundary distance (MEl et al., 2018).

According to Almeida (2012), an intuitive interpretation for Moran's I negative and significant bivariate can be explained as follows: real estate (apartments or houses) that are closest to parks and woods tend to be surrounded by properties in the vicinity that present higher sales prices and vice-versa (WÜSTEMANN et al., 2017). In addition, it was found that people with higher family incomes have access to green areas with better quality (SCHRÖDER-BÄCK, 2012), infrastructure and security, since the properties located near these areas have a higher value (WÜSTEMANN et al., 2017), exemplified in the green area Airumã. Another intuitive interpretation given to the spatial weight matrix adopted is that the negative and significant global spatial dependence implies that the real estate (apartments and houses) closest to parks and forests tend to have higher selling prices than properties located farther away from these areas (PANDURO et al., 2013). In the case of apartments, decreasing their distance from a park in the central region of the city increases its price, with the effect gradually declining when the distance to the CBD increases. While, in turn, reducing the distance of an apartment to woods on the outskirts of Curitiba increases its price.

The effect of parks and forests on apartment prices is not stationary in urban space due to the heterogeneity of economic and social conditions or even the management of these green areas. Treating these areas as a homogeneous good is misleading (PANDURO et al., 2013), since cities, as a rule, are not monolithic organisms, and must necessarily create solutions considering these dynamics. As for the houses, it is observed that decreasing their distance from the park on the outskirts of the city increases its price; while reducing its distance from forests in the central region and the periphery increases its price. It was evidenced 
that any solution will have geographically variable effects due to the structural heterogeneity of the city, especially in the center and the periphery (VOTSIS, 2017).

It is necessary to observe, based on the analysis presented, that the presence of urban green areas, currently around $18 \%$ of the territory of Curitiba, contributes to the appreciation of real estate, as well as to the quality of life of the population of the city and metropolitan region. Regarding the effects of the green areas Airumã, Repar and Teresa Urban, it has been detected that they can be positive or negative. In the case of Airumã PRNHM it can be inferred that it has a positive and significant effect on the prices of apartments and houses located closer to its neighborhood. In addition, it found that within a radius of 10,000 meters preliminary estimates are that the green area Airumã can increase prices of apartments and houses respectively, on average, by $4.4 \%$, and $6.3 \%$.

A consistent hypothesis to justify this increase in real estate value is the perception of stakeholders stating the present or future scarcity of these urban green areas. Moreover, it must be considered that macroeconomic conditions and problems related to unemployment rates may contribute to a change in estimates. On the other hand, it can be inferred that the green areas Repar and Teresa Urban cause negative effect (positive sign of the estimated coefficient) but not significant in Curitiba apartment prices within a tested radius of 5,000 meters and for the complete sample. This result should be considered with some caution due to sample limitations.

In addition, it can be inferred that these green areas have a more significant negative and significant effect on the prices of houses located closer to their surroundings, that is, they represent a burden on the owners. The DT5000 and DR5000 variables have estimated negative coefficients, on average, of $7 \%$ and $18 \%$ of the value of the property, since the infrastructure of these areas, such as safety, size and proximity to the vegetation remnant, may also have an impact on the price of real estate (PANDURO et al., 2013). The impacts of the amenities generated by these areas on real estate values may be different from those in other developed or less polluted areas (MEI et al., 2018) and with low rates of violence.

Despite this, the ecosystem services provided by the urban green areas are undeniable, such as: air quality, barrier to noise pollution, temperature regulation, aesthetic effects (SANDER et al., 2010), cultural services, such as recreation, protection of fauna and flora, among others, provide positive externalities that improve the quality of life (HUBACEK et al., 2013), or for the direct or indirect use of these areas. The provision of ecosystem services may vary by type and size. Nevertheless, these amenities often end up not being considered in the value of the property (CZEMBROWSKI et al., 2016), a perspective that might be overcome with appreciation of the ecosystem services provided by urban green areas.

\section{CONCLUSIONS}

The results suggest that in Curitiba in general: a) The more distant a property is located from the commercial center and services (CBD) the lower its selling price, while the proximity of the property of urban green areas contributes to the rise in the price of the square meter of housing, however, real estate valuation should not be interpreted in a linear manner; b) The effects of the proximity of the urban green areas on the 
price of urban residential properties are not homogeneous and stationary along the urban space, being able to generate distinct spatial clusters of real estate prices; c) Green areas such as Airumã, because they are located near the CBD, have good urban infrastructure, high monthly income and zero homicide rates and general occurrences, contribute positively to the formation of the price of real estate in their neighborhood. On the other hand, peripheral green areas such as Teresa Urban and Repar, inserted in neighborhoods with low monthly income, high homicide rates and other general occurrences, impact property prices in an opposite way, the further from a green area, the lower the price; d) The results obtained in the application of hedonic price theory and spatial econometric techniques can be an important subsidy to guide the formulation of an urban management model that promotes the valuation of urban green areas, as well as their remuneration through Payment for Environmental Services (PSA), considering the high potential for the use of information, processing and analysis of data and results generated; e) The revealed heterogeneity in house prices according to the distance of the urban green areas, inserted in different socioeconomic contexts suggests that the strategies for the definition of economic instruments and/or public policies for valuation of green areas, including Payment for Environmental Services (PSA), should be implemented in a sectorized way, by region, or even by neighborhood, considering the control variables described in the econometric model presented.

\section{REFERENCES}

ALMEIDA, E.. Econometria Espacial Aplicada. Campinas: Alínea, 2012.

BAJARI, P.; FRUEHWIRTH, J. C.; KIM, K.; TIMMINS, C.. A Rational Expectations Approach to Hedonic Price Regressions with Time-Varying Unobserved Product Attributes: The price of pollution. American Economic Review, v.102, n.5, p. 8981926, 2012. DOI: https://doi.org/10.1257/aer.102.5.1898

BARDDAL, M. L.; RODERJAN, C. V.; GALVÃO, F.; CURCIO, G. R.. Caracterização florística e fitossociológica de um trecho sazonalmente inundável de Floresta Aluvial, em Araucária, PR. Ciência Florestal, Santa Maria, v.14, n.2, p.37-50, 2004.

BATEMAN, I. J.; MACE, G. M.; FEZZI, C.; ATKINSON, G.; TURNER, K.. Economic analysis of eco-system service assessments. Environmental and Resource Economics, v.48, n.2, p.177-218, 2010. DOI: https://doi.org/10.1007/s10640$\underline{010-9418-x}$

BRINK, P.. The Economics of Ecosystems and Biodiversity in National and International Policy Making: TEEB - The Economics of Ecosystems and Biodiversity. Earthscan: London and Washington, 2011.

CHO, S.-H.; LAMBERT, D. M.; KIM, S. G.; ROBERTS, R. K.; PARK, W. M.. Relationship between value of open space and distance from housing locations within a community. Journal of Geographical Systems, v.13, n.4, p.393-414, 2011. DOI: https://doi.org/10.1007/s10109-010-0126-4

COMEC. Coordenação da Região Metropolitana de Curitiba. População total, urbana e rural dos municípios da Região Metropolitana de Curitiba - 2010. COMEC, 2012.
CURITIBA. Prefeitura Municipal de Curitiba. Plano Municipal de Conservação e Recuperação da Mata Atlântica Curitiba PR. Curitiba: Prefeitura Municipal de Curitiba, 2012.

CZEMBROWSKI, P.; KRONENBERG, J.. Hedonic Pricing and Different Urban Green Space Types and Sizes: insights into the discussion on valuing ecosystem services. Landscape and Urban Planning, v.146, p.11-19, 2016. DOI: https://doi.org/10.1016/i.landurbplan.2015.10.005

FREEMAN, A. M.; HERRIGES, J. A.; KLING, C. L.. The Measurement of Environmental and Resource Values. 3 ed. Oxford: RFF Press, 2014.

GAMPER-RABINDRAN, S.; TIMMINS, C.. Hazardous Waste Cleanup, Neighborhood Gentrification, and Environmental Justice: Evidence from Restricted Access Census Block Data. American Economic Review, v.101, n.3, p.620-624, 2011. DOI: https://doi.org/10.1257/aer.101.3.620

GERKMAN, L.. Empirical spatial econometric modeling of small-scale neighborhood. Journal of Geographical Systems, v.14, n.3, p.283-298, 2012. DOI: https://doi.org/10.1007/s10109-011-0147-7

HAURU, K.; LEHVÄVIRTA, S.; KORPELA, K.; KOTZE, D. J.. Closure of view to the urban matrix has positive effects on perceived restorativeness in urban forests in Helsinki, Finland. Landscape \& Urban Planning, v.107, n.4, p.361-369, 2012. DOI: https://doi.org/10.1016/j.landurbplan.2012.07.002

HUBACEK, K.; KRONENBERG, J.. Synthesizing different perspectives on the value of urban ecosystem services. Landscape and Urban Planning, v.109, n.1, p.1-6, 2013. DOI: http://dx.doi.org/10.1016/i.landurbplan.2012.10.010 
IBGE. Instituto Brasileiro de Geografia e Estatística. Portal Cidades. Rio de Janeiro: IBGE, 2015.

IPPUC. Instituto de Pesquisa e Planejamento Urbano de Curitiba. Curitiba em dados. IPPUC, 2014.

JOHN, E. M. C.. Análise de preços hedônicos no mercado imobiliário de apartamentos em Curitiba. Dissertação (Mestrado em Desenvolvimento Econômico) - Universidade Federal do Paraná, Curitiba, 2014.

KERSTEN, R. A.; GALVÃO, F.. Aspectos da Paisagem do Município. In: STRAUBE, F. C.; CARRANO, E.; SANTOS, R. E. F.; SCHERER-NETO, P.; RIBAS, C. F.; MEIJER, A. A. R.; VILLEGAS, M.; LANZER, M.; KLEMANN-JÚNIOR, L.; AURÉLIO-SILVA, M.; URBEN-FILHO, A.; ARZUA, M.; LIMA, A. M. X.; SOBÂNIA, R. L. M.; DECONTO, L. R.; BISPO, A.; JESUS, S.; ABILHOA, V.. Aves de Curitiba: coletânea de registros. Curitiba: Hori Consultoria Ambiental, 2014. p.31-89.

LARSON, E. K.; PERRINGS, C.. The value of water-related amenities in an arid city: The case of the Phoenix metropolitan area. Landscape and Urban Planning, v.109, n.1, p.45-55, 2013. DOI:

http://dx.doi.org/10.1016/j.landurbplan.2012.10.008

MEI, Y.; ZHAO, X.; LIN, L.; GAO, L.. Capitalization of Urban Green Vegetation in a Housing Market with Poor Environmental Quality: Evidence from Beijing. Journal of Urban Planning and Development, v.144, n.3, 2018. DOI: https://doi.org/10.1061/(asce)up.1943-5444.0000458

PANDURO, T. E.; LAUSTED-VEIE, K.. Classification and valuation of urban green spaces: $A$ hedonic house price valuation. Landscape and Urban Planning, v.120, p.119-128, 2013. DOI: https://doi.org/10.1016/i.landurbplan.2013.08.009

PERINO, G.; ANDREWS, B.; KONTOLEON, A.; BATEMAN, I.. The Value of Urban Green Space in Britain: A methodological framework for spatially referenced benefit transfer. Environmental \& Resource Economics, v.57, n.2, p.251-272, 2014. DOI: http://hdl.handle.net/10.1007/s10640-013-96658.

A CBPC - Companhia Brasileira de Produção Científica (CNPJ: 11.221.422/0001-03) detém os direitos materiais desta publicação. Os direitos referem-se à publicação do trabalho em qualquer parte do mundo, incluindo os direitos às renovações, expansões e disseminações da contribuição, bem como outros direitos subsidiários. Todos os trabalhos publicados eletronicamente poderão posteriormente ser publicados em coletâneas impressas sob coordenação da Sustenere Publishing, da Companhia Brasileira de Produção Científica e seus parceiros autorizados. Os (as) autores (as) preservam os direitos autorais, mas não têm permissão para a publicação da contribuição em outro meio, impresso ou digital, em português ou em tradução.
SANDER, H.; POLASKY, S.; HAIGHT, R. G.. The value of urban tree cover: A hedonic property price model in Ramsey and Dakota counties, Minnesota, USA. Ecological Economics, v. 69, n. 8, p. 1646-1656, 2010. DOI: https://doi.org/10.1016/j.ecoleco n.2010.03.011

SCHRÖDER-BÄCK, P.. Ethische Kriterien der Gerechtigkeit für den Zusammenhang von Umwelt und Gesundheit. In: BOLTE, G.; BUNGE, C.; HORNBERG, C.; KÖCKLER, H.; MIELCK, A.. Umweltgerechtigkeit: Chancengleichheit bei Umwelt und Gesundheit. Konzepte, Datenlage und Handlungsperspektiven. Bern: Hogrefe, 2012. p.51-60.

SIRIWARDENA, S. D.; BOYLE, K.; HOLMES, T.; WISEMAN, P. E.. The implicit value of tree cover in the U.S.: A meta-analysis of hedonic property value studies. Ecological Economics, v.128, p.68-76, 2016. DOI: https://doi.org/10.1016/i.ecolecon.2016.04.016

SOCIEDADE CHAUÁ; PROFLOR CONSULTORIA AMBIENTAL. Plano de Manejo da Reserva Particular do Patrimônio Natural Municipal Airumã - Curitiba, PR. Curitiba, 2013.

UN. United Nations. World Urbanization Prospects: The 2014 Revision, Highlights (ST/ESA/SER.A/352). New York: United Nations, 2014.

VOTSIS, A.. Planning for green infrastructure: The spatial effects of parks, forests, and fields on Helsinki's apartment prices. Ecological Economics, v.132, p.279-289, 2017. DOI: https://doi.org/10.1016/j.ecolecon.2016.09.029

WÜSTEMANN, H.; KOLBE, J.. Der Einfluss städtischer Grünflächen auf die Immobilienpreise: Eine hedonische Analyse für die Stadt Berlin. Raumforsch Raumordn, v.75, p.429-438, 2017. DOI: https://doi.org/10.1007/s13147-017$\underline{0485-0 .}$.

ZYGMUNT, R.; GLUSZAK, M.. Forest proximity impact on undeveloped land values: A spatial hedonic study. Forest Policy and Economics, v.50, p.82-89, 2015. DOI: https://doi.org/10.1016/i.forpol.2014.07.005 